Journal of European Public Policy

ISSN: 1350-1763 (Print) 1466-4429 (Online) Journal homepage: http://www.tandfonline.com/loi/rjpp20

\title{
The impact of the Eastern enlargement on the decision-making capacity of the European Union
}

\section{Dimiter D. Toshkov}

To cite this article: Dimiter D. Toshkov (2017) The impact of the Eastern enlargement on the decision-making capacity of the European Union, Journal of European Public Policy, 24:2, 177-196, DOI: $10.1080 / 13501763.2016 .1264081$

To link to this article: https://doi.org/10.1080/13501763.2016.1264081

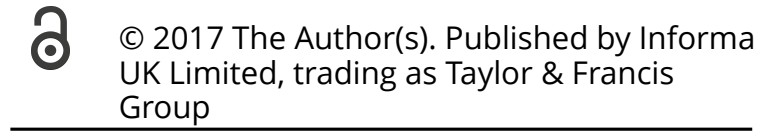

\section{+ View supplementary material $\widetilde{ }$}

曲 Published online: 07 Feb 2017.

Submit your article to this journal $\sqsubset$

Џll Article views: 2030

View Crossmark data $₫$

4 Citing articles: 6 View citing articles $\pi$ 


\title{
The impact of the Eastern enlargement on the decision-making capacity of the European Union
}

\author{
Dimiter D. Toshkov \\ Institute of Public Administration, Leiden University, The Hague, The Netherlands
}

\begin{abstract}
This contribution investigates the impact of the Eastern enlargement on the decision-making capacity of the European Union. On the basis of new data on the number and types of legal acts produced by the EU (1994-2014) and on the time between the proposal and adoption of legislative acts (19942012), the contribution argues that enlargement has had a rather limited impact on legislative production and duration and that it is extremely hard to disentangle this impact from other contemporaneous institutional and socioeconomic developments. On the basis of analyses of expert-based policy positions of member states in EU negotiations and on voting data from the Council of Ministers of the EU, it is argued that enlargement has possibly added a new dimension of contestation in EU legislative decision-making, but one that concerns a relatively small share of all negotiations in few policy fields like environment. All in all, there is no evidence that the Eastern enlargement has led to the institutional gridlock and loss of decision-making capacity that the public, many politicians and some academics as well have feared.
\end{abstract}

KEYWORDS Decision making; enlargement; European Union; legislative duration; legislative production; political conflict

\section{Introduction}

When, in the early autumn of 2015, the governments of Hungary, Slovakia, Romania and other Central and East European (CEE) states strenuously opposed the proposal for refugee resettlement quotas supported by Germany, France, Italy and other West European states, ${ }^{1}$ it seemed like this is just the latest sign of the disfunctionality of the current EU decisionmaking system; yet another symptom of a general malaise the EU brought upon itself with the big-bang Eastern enlargement in 2004 and 2007. Such impressions were only reinforced later in the year, when seven of the 'new'

CONTACT Dimiter D. Toshkov dtoshkov@fsw.leidenuniv.nl

$(1)$ Supplemental data for this article can be accessed at http://dx.doi.org/10.1080/13501763.2016. 1264081

(c) 2017 The Author(s). Published by Informa UK Limited, trading as Taylor \& Francis Group

This is an Open Access article distributed under the terms of the Creative Commons Attribution-NonCommercial-NoDerivatives License (http://creativecommons.org/licenses/by-nc-nd/4.0/), which permits non-commercial re-use, distribution, and reproduction in any medium, provided the original work is properly cited, and is not altered, transformed, or built upon in any way. 
member states signed an open letter addressed to the European Commission in which they opposed Germany's plans to double the capacity of the Nord Stream gas pipeline that connects Northern Europe directly with Russia, bypassing conflict-torn Ukraine. ${ }^{2}$ These two cases fit comfortably into a general narrative about the deleterious effect of enlargement on the EU's capacity to take action and adopt enforce new policies. Despite the pervasiveness of this narrative and the available anecdotal evidence, however, the question about systematic impact of the Eastern enlargement on the decision-making capacity ${ }^{3}$ of the EU actually still remains unanswered.

In this contribution, I address this open question on the basis of a comprehensive analysis of primary data and a review of secondary literature. I investigate the systematic effects of enlargement on the volume of legislative production, on the speed of legislative decision-making, and on the underlying conflict space in the Council of Ministers. I use a variety of data sources, including the official EU legislative databases Eur-lex and Pre-lex, the voting records of the Council of Ministers of the EU, and measures of member states' policy positions as recorded by political scientists.

In contrast to much of the existing academic literature (in particular, Hertz and Leuffen [2011]; König [2007]; König and Bräuninger [2002]; Leuffen [2006]; Leuffen and Hertz [2010]; Settembri [2007]; see also Avery et al. [2009]; Plechanovova [2011]; Thomson [2009]; Zimmer et al. [2005]; for more nuanced positions, see Hagemann and De Clerck-Sachsse [2007]; Kelemen et al. [2014]) and the dominant public discourse, ${ }^{4}$ I find that the Eastern enlargement has not had a major negative effect on the decision-making capacity of the EU. If anything, the speed of decision-making for some important types of legal acts has actually increased, and more legislation is being produced after 2004 than in the 10 years preceding the accession of the first post-communist countries to the EU. While the precise effect of enlargement remains impossible to disentangle from all other contemporarious institutional, political, and societal developments that affected the EU, it is that the EU decision-making system has not ground to a halt, it has not been crippled by an East-West conflict, it has not been paralyzed in a gridlock in the aftermath of the accession of 13 new member states since 2004.

There is some suggestive evidence, however, that a new dimension has appeared in the analytic conflict space characterizing negotiations in the Council of Ministers; a dimension that seems related, if imperfectly so, to the accession of the 'new' member states. This conflict dimension is discernable more clearly when we look at policy positions, but even then it characterizes a relatively small share of all legislative proposals (cf. Mattila 2009, Plechanovova 2011; Thomson 2009). Accordingly, when we examine voting records, it appears that only in a few policy areas, such as asylum and climate change, the 'new' member states cluster together in opposition to a relative cohesive group of the 'old' member states. In many other areas, they split to reinforce existing conflicts in the Council. Moreover, even 
when the Central and East European countries adopt similar positions, they are seldom able to block or significantly delay the adoption of legislation. In short, even when the 'new' member states have similar preferences that enable them to act as a group, they are too small and too few to derail the decision-making process. All in all, while enlargement might have altered the mode of decision-making in the EU and added a new cleavage in the Council, the decision-making machinery has retained a level of efficiency and effectiveness comparable to the period preceding 2004.

This conclusion is important in light of the widely shared anxieties and the common narrative about the negative effects enlargement must have had on the EU's capacity to adopt and enforce new laws and policies. Such fears, even if based on, as I argue below, biased and selective interpretation of the available evidence, still affect the way the Eastern enlargement is perceived and assessed by citizens and élites, and they also inform and constrain the possibilities for future expansion of the EU.

\section{Theoretical expectations}

Before we proceed to the empirical analyses, it is worth pausing for a moment and reviewing the theoretical reasons why and how enlargement should affect decision-making capacity. In fact, there are plenty of theoretical arguments that would lead us to expect large effects.

To start with, consider the common 'spatial model' paradigm for analysing legislative decision-making, rooted in rational choice theory (Enelow and Hinich 1984). ${ }^{5}$ According to this paradigm, legislative decision-making outcomes result from the interplay of the preferences of the actors involved and the institutional setting (understood as the rules of the game). Hence, the addition of new actors (players) to the negotiation game per se does not affect the outcomes, but the changes in the constellation of relevant actors' preferences might significantly affect the outcomes of individual negotiations and systematically undermine the capacity of the decision-making system as a whole. If the addition of new actors increases the preference heterogeneity within the set of decision-makers, under restrictive voting rules that would make departures from the status quo more difficult and at some point impossible. Hence, one likely effect of enlargement in theoretical terms is increased policy stability or, to put it in less positive terms, gridlock and inability to produce new and amend existing policies, provided that the accession of the new member states increases the preference heterogeneity in the EU along the relevant conflict dimensions.

It is important to realize that the inclusion of new players is not a sufficient condition for gridlock - the preferences of new actors can also be 'absorbed' so that the expected outcomes under the given preference configuration remain the same (Steunenberg 2002; Tsebelis 2002). Therefore, in order to examine empirically whether enlargement has had an impact on decision-making 
capacity, we need to investigate the changes it brought to the preference heterogeneity within the Council and to the underlying structure of the policy conflict space.

According to complete information versions of the spatial model, actors anticipate their reactions and act accordingly. One implication of this logic is that policy and legislative proposals that would not be approved would not be made in the first place. Therefore, the rate of rejected proposals is not necessarily a good indicator of reduced decision-making capacity (see also Häge and Toshkov 2011). Since the rejection or non-agreement rate is not very useful, the amount of policy and legislative proposals made and decisions and laws adopted over time would appear to be a better alternative to evaluate decision-making capacity. This, however, requires that we assume the size of the systemic agenda, or the set of issues that the EU should make policies and decisions about, remains constant over time.

In principle, complete information spatial models of legislative decisionmaking also hold no implications about the duration of decision-making. Nevertheless, it is often assumed (for example, König 2007; Klüver and Sagarzazu 2013) that preference heterogeneity and distance between the actors increases the amount of time needed to reach a common decision.

Finally, note that within the spatial paradigm the effect of preferences is conditional on the institutional rules (about voting, agenda-setting and amending rights, sequence of moves, etc.) Therefore, under tight supermajoritarian voting requirements, the effect of preference heterogeneity might be one of gridlock, as explained above. But under loose voting rules and open agenda-setting, it can lead to the opposite outcome, namely frequent policy changes and decision reversals, as coalitions can be easily constructed to defeat any status quo.

In addition to the hypothesized effect of enlargement that works mostly through the changing preferences (interests) represented in the EU (that underpins the logic of the spatial models discussed above), sociological and social psychological theories suggest additional causal channels and mechanisms (for an overview, see Bailer et al. 2009; Kelemen et al. 2014). According to these theories, the mere number of participants matters a great deal because it affects communication patterns, consensus-forming, the level of formalization and the mode of decision-making more generally. While certainly plausible, it is not entirely clear how such mechanisms would affect the decision-making capacity of the EU as such. For example, enlargement could have eroded the consensus culture in the Council, but that could have actually increased the capacity to take decisions.

In summary, social science theories provide plenty of propositions about how enlargement could have affected decision-making in the EU. The plethora of plausible mechanisms make it easy to jump to the conclusion 
that because it could have, enlargement has affected the capacity of the EU to take decisions. But the empirical evidence points in a different direction.

\section{Empirical analyses}

In this section, I review systematically the empirical evidence about the impact of the Eastern enlargement on the decision-making capacity of the EU. The review is based both on a critical analysis of secondary sources (published academic articles and policy papers), as well as primary data where appropriate. The analysis focuses consecutively on legislative output, legislative duration, and the nature of the conflict space in the Council of Ministers.

\subsection{Legislative output}

Legislative output, defined as the amount of binding legislative acts that the EU adopts, is a primary indicator of its decision-making capacity. ${ }^{6}$ Effective political and policy-making systems need to be able to respond to societal problems by producing laws and regulations. The inability to do so, reflected in a diminishing legislative output, would be a major symptom of political paralysis and institutional gridlock.

Three existing studies suggest that the impact of enlargement on the EU's legislative output has been negative (Hagemann and De Clerck-Sachsse 2007; Leuffen and Hertz 2010; Plechanovova 2013).

Turning to the analysis of primary data, Table 1 shows the total number of legislative acts ${ }^{7}$ adopted over four aggregated time periods, two before and two after the 2004 enlargement: mid-1994 to mid-1999; mid-1999 to mid2004; mid-2004 to mid-2009; and mid-2009 to mid-2014. The periods have been defined as to correspond with the terms of the European Parliament, which, especially in the more recent years, influence the legislative production cycle significantly. The table shows that there is no clear trend when it comes to legislative output. The number of regulations adopted by the Council, or by the Council and the EP under the codecision/ordinary legislative procedure, has been reduced from more than 1,200 during the 1994-1999 period to around 850 afterwards. But the decline happens long before the Eastern enlargement, so it cannot be attributed to its impact.

Table 1. Dynamics of EU legislative output over time.

\begin{tabular}{|c|c|c|c|c|c|c|}
\hline & \multicolumn{3}{|c|}{ Council or Council \& EP } & \multicolumn{3}{|c|}{ Commission } \\
\hline & Regulations & Directives & Decisions & Regulations & Directives & Decisions \\
\hline 1 July 1994-30 June 1999 & 1,275 & 247 & 856 & 11,994 & 210 & 2,623 \\
\hline 1 July 1999-30 June 2004 & 827 & 276 & 1,131 & 11,667 & 246 & 2,714 \\
\hline 1 July 2004-30 June 2009 & 854 & 220 & 1,340 & 7,749 & 268 & 2,213 \\
\hline 1 July 2009-30 June 2014 & 876 & 206 & 1,815 & 5,696 & 267 & 1,733 \\
\hline
\end{tabular}


The number of Council and Council/EP directives, which arguably represent many of the most important legislative acts that the EU adopts, drops slightly since mid-2004, but the decrease is relatively small (around 20 per cent) and is accompanied by a corresponding increase in the number of Commission directives adopted.

The nature of Commission legislation also changes over the observation period, with the introduction of delegating and implementing acts with the Treaty of Lisbon, so it is very hard to say whether the decrease in 'regular' directives is in a way compensated by the rise of implementing/delegated legislation or the two phenomena are unrelated. Interestingly, when it comes to decisions, the trend is the opposite - while the number of Commission decisions drops over time, the number of Council/Council and EP decisions increases.

Altogether, the numbers reported in Table 1 do not provide evidence for a strong negative effect of the Eastern enlargement on the capacity of the EU to produce legislation. ${ }^{8}$ What we observe are fluctuations in the productivity over time and a changing mix of the legislative output in terms of types of legal acts. But a major decrease in legislative output caused by enlargement seems to be ruled out by the data.

\subsection{Legislative duration}

The overall output of the EU might not have been affected, but perhaps the duration of legislative decision-making has increased dramatically? As with justice, regulation delayed is regulation denied, so legislative duration is a significant problem in its own right.

The existing academic literature offers conflicting accounts. Some studies argue that enlargement has or would slow down decision-making (Hertz and Leuffen 2011; König 2007). On the other hand Golub (2007) finds no effect of enlargements (his data do not include the Eastern enlargement) and Klüver and Sagarzazu (2013) report no effect of the number of member states and a negative effect of within-Council ideological diversity on legislative duration. Best and Settembri's (2008) descriptive analysis also finds no effect of the Eastern enlargement.

With these remarks in mind, let us look into the duration of legislative decision-making before and after May 2004. The left panel of Figure 1 plots the Kaplan-Meier survival curves for the time between Commission proposal and signature by the Council and EP for all legal acts ${ }^{9}$ proposed under codecision/ordinary legislative procedure between July 1994 and the end of 2012. The two curves - one for acts proposed until 1 May 2004 and another for acts proposed afterwards - trace the proportion of non-adopted acts over time. We can see that there are no discernible differences in the 'survival' rate of pre- and post-enlargement proposals, meaning that the duration of decision-making remains very similar. 

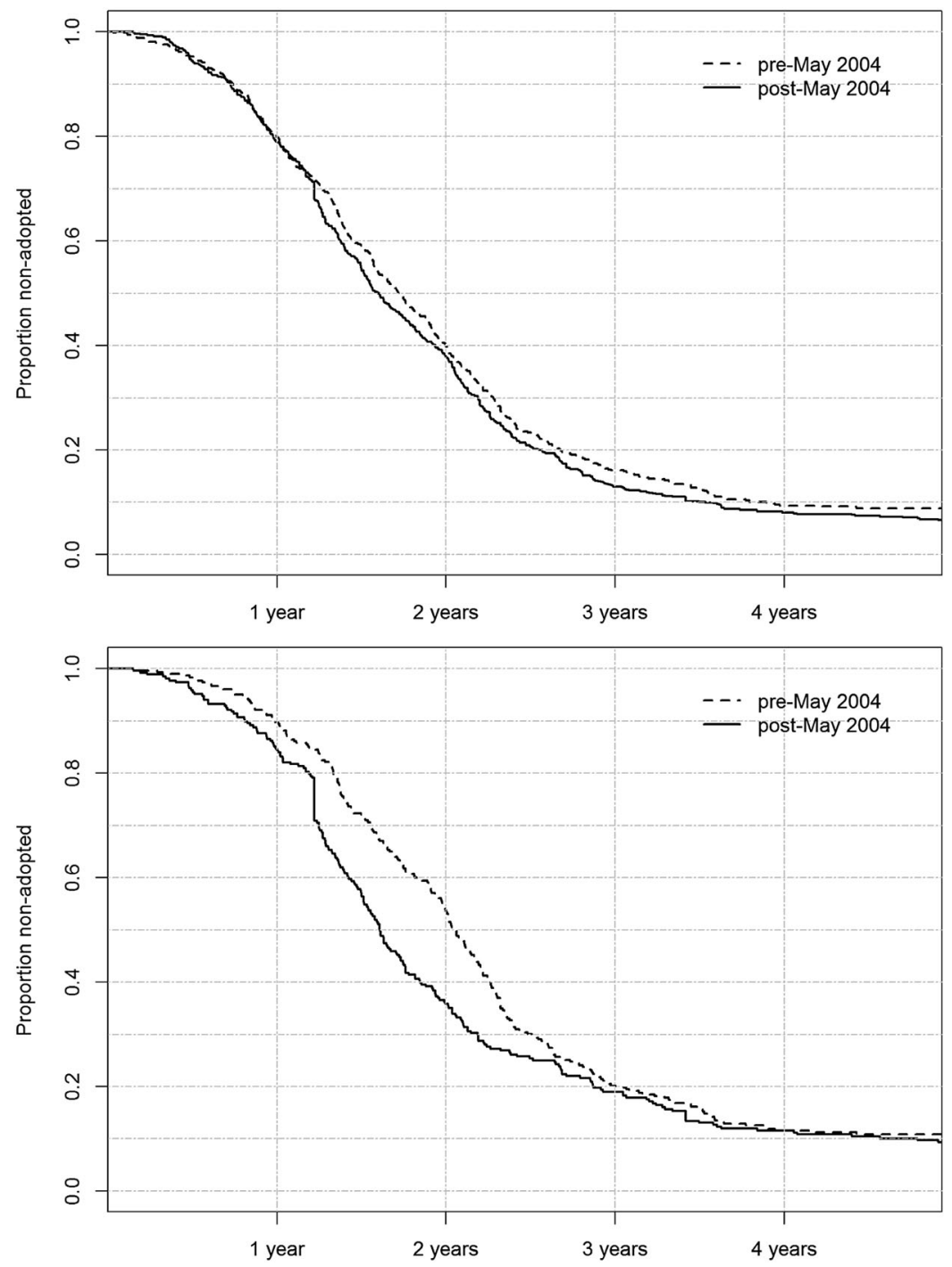

Figure 1. Duration of legislative decision-making in the EU (1994-2012). Left: all legal acts under codecision/ordinary legislative procedure. Right: directives only.

Zooming in to directives only, the right panel of Figure 1 shows the associated survival curves. We can see that, actually, post-2004 legislative decisionmaking concerning this very important type of EU legal acts is faster than before. For example, more than 60 per cent of the post-enlargement directive proposals have been adopted by the two-year mark, but a little less than 50 per cent of the pre-enlargement directive proposals.

The difference is moderate and is probably at least partly owing to the increased use of early agreements after 2004 (Toshkov and Rasmussen 
2012), but it is in a direction that does not suggest that enlargement slowed down significantly inter-institutional decision-making in the EU. Other relevant institutional developments that confound the differences in duration before and after enlargement include the use of public consultations in the preparation of legal drafts (Rasmussen and Toshkov 2013), transparency initiatives in the Council (Lenz and Hagemann 2014), and the involvement of national parliaments via the scrutiny procedure (Hagemann et al. 2014).

Altogether, we can say that the combined impact of enlargement and the other contemporarious institutional and procedural changes on legislative duration has been a small one, with some legal acts adopted faster than before (e.g., directives under the ordinary legislative procedure), while others perhaps slower.

\subsection{Preference heterogeneity and the nature of the conflict space A: policy positions}

Many, though not all, theoretical expectations about the possible effects of enlargement on legislative output and duration are derivative from its hypothesized impact on the conflict space and preference heterogeneity within and between the EU institutions. Hence, it is worth searching for influence of enlargement directly on these two aspects of legislative decisionmaking in the Council of Ministers, where most of the conflicts between the member states are played out. This section of the article reports analyses based on two different and complementary data sources - member states' policy positions measured in the framework of the DEU-II project (Thomson et al. 2012) and voting records. Previous studies also use indirect proxies for member states' preferences, such as socioeconomic fundamentals (König and Bräuninger 2004; Zimmer et al. 2005) and governing party policy platforms (Veen 2011).

First, let us look into the issue position data ${ }^{10}$ derived from the DEU-II project (Thomson et al. 2012). Analysing this data graphically with a multidimensional scaling (MDS) analysis, Thomson (2009: 767, 2011) finds evidence that the post-2004 member states contribute to a new East-West conflict dimension, but one related to a relatively small proportion of all policy issues. A similar MDS analysis leading to compatible conclusions is reproduced and reported in the Online Appendix of this article (Figure A1).

To complement the general picture presented by the MDS, we can examine how the CEE member states are positioned on the individual proposals included in the DEU-II dataset with regard to two crucial questions - do they cluster together, and do they influence significantly the difference between the Commission's position and the eventual outcome? Table 2 presents the results of the analysis. It takes into account the position configurations and distances of all 12 'new' member states (NMS-12). In the Online 
Table 2. Policy issue position configurations of the Commission, the negotiation outcome and the post-2004 (new) member states (NMS-12).

\begin{tabular}{lccc}
\hline & $\begin{array}{c}\text { Number of } \\
\text { policy issues }\end{array}$ & $\begin{array}{c}\text { Final outcome } \\
\text { close to NMS }\end{array}$ & $\begin{array}{c}\text { Final outcome } \\
\text { far from NMS }\end{array}$ \\
\hline New member states (NMS) split & 36 & 18 & 18 \\
New member states (NMS) together & 79 & 38 & 37 \\
- and close to the Commission & 28 & 18 & 9 \\
- and away from the Commission & 51 & 20 & 28 \\
\hline
\end{tabular}

Appendix, a more detailed version of this table (Table A1) also shows the calculations only for the post-communist 'new' member states (hence, excluding Cyprus and Malta; NMS-10) and for the so-called 'Visegrad 4' countries (the Czech Republic, Hungary, Poland and Slovakia; V-4) that have a special institutionalized mechanism for multilateral co-operation and co-ordination of EU affairs.

From the 115 policy issues on which there are 7 or more (out of 12 possible) positions of new member states recorded in the data, on 79 there are relatively small differences (a within-group standard deviation less than 21 on a 100-point scale or only one state with a different opinion than the rest). In the remaining 36 issues (31 per cent of all) there are significant differences between the positions of the 12 new member states. When the positions of the new member states are clustered close together, the final negotiation outcome is close to their position (within 20 points) in approximately half of the cases (38 vs 37 for the NMS-12).

In two-thirds of the cases when the new member states are clustered together, their average position is far away (further than 20 points) from the Commission's. If the member states are clustered together and relatively close to the Commission's position, the final outcome is close to their position in two-thirds of the cases (18 vs 9). If they are distant from the Commission's position, the final outcome is close to their position in less than half of the cases (42 per cent, 20 vs 28 cases).

Interestingly, from the 20 cases in which a tight group of the new member states ends up close to the outcome despite the differences with the Commission, in eight cases the status quo is protected and in four cases the outcome is moved closer to the new member states' position despite the Commission being satisfied with the status quo (in two cases the difference is split and in six cases there is no information on the pre-negotiation status quo).

From all 28 cases where the member states are close together and close to the status quo, the final outcome is away from the status quo in 15 cases (in other words, a tight group of the new member states cannot protect the preferred status quo in more than half of the cases). And this is more likely to happen if the status quo does not enjoy the support of the Commission.

Altogether, the conclusion is that on two-thirds to three-quarters of the policy issues the new member states are grouped close together (note that 
this includes issues which might have had little salience to these member states). The new member states end up close to the outcome of the decision-making processes in half of all cases, but much more often if they happen to be close to the Commission's position than otherwise. When the new member states 'win' despite the Commission's position, it is more often in protecting the status quo than in producing policy change. Still, the new member states manage to protect the preferred status quo, even when they have very similar positions, in only half of the cases (and it could still be that they happen to be 'lucky' to share the position of other powerful member states or of the EU institutions).

\subsection{Preference heterogeneity and the nature of the conflict space B: voting records}

Having presented the analysis of policy position data, we turn towards the analysis of data on roll-call voting in the Council of Ministers of the EU. ${ }^{11}$ The advantage of voting data is that they are available for more proposals. But there are disadvantages as well. ${ }^{12}$ First, even if we assume that member states sincerely record their disagreement with the final text of a legal act through a negative vote or an abstention, that still only indicates whether they prefer the status quo (or some other references point) to the negotiation outcome. The expert-derived policy positions analysed above allow for more nuances in measuring the preferences. Second, and more importantly, the assumption of sincere voting is hard to sustain, as member states' governments cater also to national publics during EU-level negotiations. Hence, a recorded negative vote might as well express disagreement with the substance of the proposal as signal a position to the national publics.

Despite these complications, roll-call voting data has a long tradition of being used to infer the political conflict space in the Council of Ministers of the EU. The existing literature, however, offers conflicting results with respect to the influence of the Eastern enlargement. While Plechanovova (2011) argues that no fundamental change has occurred, Mattila (2009) claims that a new, enlargement-related cleavage is discernible in the voting data.

The analyses reported below are based on all negative votes and abstentions ${ }^{13}$ recorded and made publicly available by the Council of Ministers of the EU between January 2007 (the accession of Bulgaria and Romania) and December 2015 (the latest available data at the time of writing). ${ }^{14}$ Altogether, there are 382 dossiers for which at least one contestation is recorded (a negative vote or an abstention), which include 179 dossiers for which more than one national delegation expressed dissent. There are different methods with which the voting data can be analysed to infer the underlying conflict space and the patterns of connections between the national positions. The 
investigation below reports the results of several techniques that provide complementary perspectives on these problems.

First, let us consider how 'close' together different national positions are and whether the CEE member states form a distinct group of delegations that often votes similarly and that differs as a group from the 'old' member states. Network analysis provides one method to analyse and visualize the linkages between countries hidden in the voting records. Figure 2 shows the resulting network based on each common expression of dissent between two countries being treated as a connection (network edge). The grey lines (edges) represent each such connection between two member states (nodes). Countries that dissent together more often are closer together, and countries that dissent with a more diverse set of partners have a more central position in the network.

The main thing to note from the network graph is that it is rather a wellconnected one, meaning that almost all member states have rather diverse and balanced sets of partners with which they have opposed acts at one time or another. There are no visible clusters as such. Most of the countries at the centre of the network are those that have overall high levels of dissent and dissent links (United Kingdom [58; 165], The Netherlands [46; 161], Denmark [42, 157], and Austria [47; 153]). ${ }^{15}$ France, Greece and Italy are set a bit further apart from the centre of the network, but they have on average lower overall levels of contestations than the other member states $(5,15$ and 13 respectively).

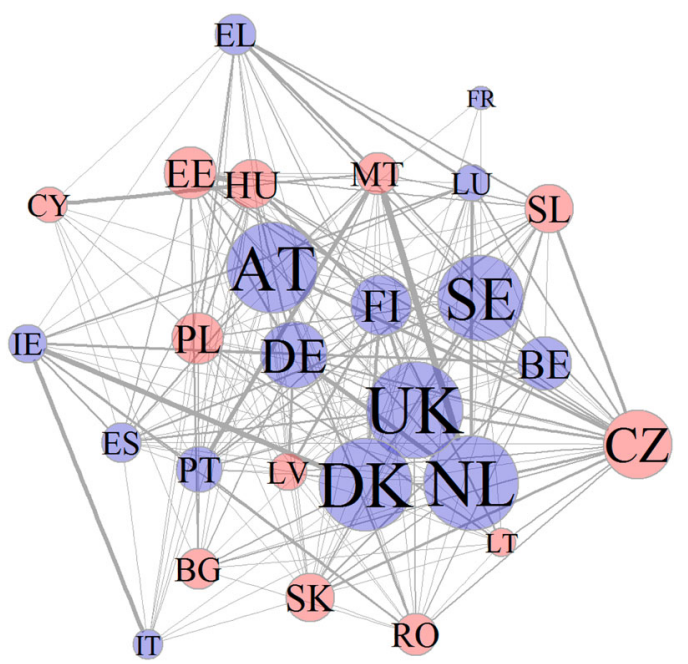

Figure 2. Network representation of common dissent (negative votes and abstentions) in the Council of Ministers (2007-2015). 
The network represented in Figure 2 is based on all dossiers (votes), so it leaves open the possibility that in particular policy areas networks of different shape and modularity exist. But it turns out that, for 10 broadly defined areas, only in the case of environment ( 26 dossiers with expressed dissent by at least one member state) can we find evidence for clustering of the CEE member states into a relatively-separated group of the total network (see Figure A2 in the Online Appendix).

The network graphs indicate that except for a small number of particular policy areas, the new member states do not often find themselves grouped together and opposed to a group of the 'old' member states. Cluster analysis is a method that can tackle more directly the question what kind of clusters can be inferred from the data, even if it is already clear that these clusters would characterize only a small part of all dossiers.

Applying hierarchical clustering ${ }^{16}$ based on the entire set of Council voting records (all policy areas), we find that one of the two top-level clusters covers Spain, Portugal, Italy, Ireland, Bulgaria, Poland, Hungary, Greece and Cyprus. So it includes some but not all of the post-2004 member states (the Czech Republic, Slovenia, Latvia, Estonia, Romania, Slovakia and Malta are not in) and some Southern European states. If anything, the cluster represents a part of the European periphery and is not related to an East-West cleavage (see Figure $A 3$ in the Online Appendix for a graph of the clustering solution).

The methods used so far provided a clue about the groupings and clustering of the member states, but not of the dimensions of the underlying conflict space as such. To derive ideal points of the member states in the latent conflict space, we can rely on the model ${ }^{17}$ developed by Clinton et al. (2004). The model's output based on a two-dimensional solution is plotted in Figure 3. The outlier on both dimensions is the United Kingdom (UK), ${ }^{18}$ which makes sense given its much higher degree of contestation of Council decisions. While the first dimension (plotted on the horizontal axis) seems to correspond roughly to net contributors to the EU budget (left side) vs net beneficiaries (right side), the second one is essentially the UK versus everyone else, with Germany and Austria anchoring the other pole. The CEE states are clustered towards the right side of the graph, but there is a lot of variation within the group (Poland on the very right side to the Czech Republic in the middle), and all of the Southern member states, Belgium, Luxembourg and Ireland are interspersed in this cluster as well.

The analysis of the evolution of the conflict space of the Council of Ministers of the EU after 2004 on the basis of different data and analytical techniques reveals a rather complex set of results. Overall, the general picture that emerges is that it is possible that the accession to the East transformed one of the dimensions of Council contestation and that the new member states help define a new axis of conflict. But given the uncertainty of 


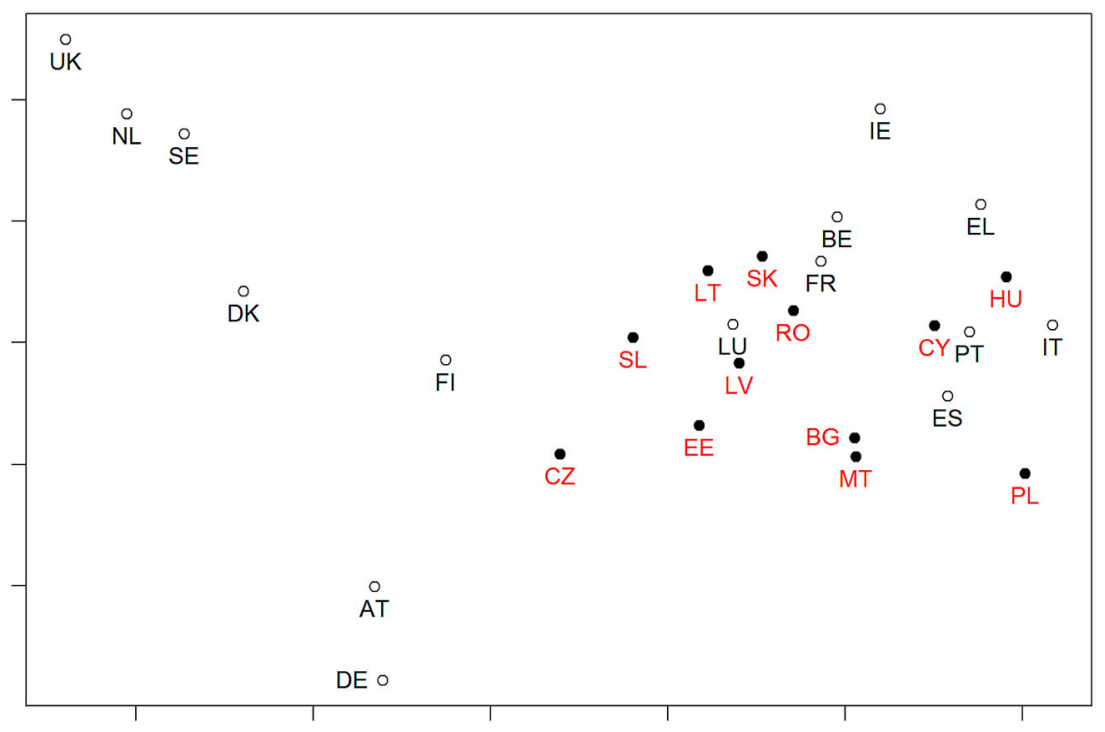

Figure 3. Inferred ideal points of the member states in the Council of Ministers (20072015). Two dimensions.

results, it is possible that this dimension is not related to enlargement per se, but to broader core vs periphery, net budget contributors vs net beneficiaries, or North/West vs South/East conflict axes.

However, even if the underlying dimension is one that pits old vs new member states, a big disclaimer is in order, since this new conflict dimension characterizes only a small part of all issues with which the Council has had to deal. As the network analyses demonstrated, clustering of old vs new member states can only be unambiguously found with regard to the policy field of environment. But owing to the fact that there is altogether not much structure in Council conflicts, even if it refers to a small set of issues, this new dimension can be detected in the aggregated data.

\section{Conclusion}

This contribution set out to assess the systematic effects of the Eastern enlargement on the decision-making capacity of the $\mathrm{EU}$ in the period from the accession of the first wave of CEE states in 2004 until 2014. I find little evidence for strong and systematic effects. But the conclusions have to remain by necessity cautious and open-ended because of the counterfactual nature of such a retrospective causal analysis. Nevertheless, given the scope and variety of evidence presented in this contribution, we can be pretty confident that accession has not had a major negative effect on the decision-making capacity of the EU. 
An analysis of the aggregate patterns of legislative production and decision-making duration before and after 2004 revealed that there are no clear trends that can be attributed to the accession of the new member states. The EU now adopts on average fewer legal acts of a certain type (e.g., regulations), but also more of other types than before (e.g., Commission directives). Legislative duration is now shorter for acts under the ordinary legislative procedure, but not much different for others. Moreover, so many other institutional changes have affected the legislative capacity of the EU in the time since 2004 that no separate causal effect can be unambiguously attributed to any of them in isolation. What is clear, however, is that there is no major breakdown of the decision-making machinery and that its capacity has not been compromised.

Enlargement appears to have been more consequential when it comes to reshaping the conflict dimensions in the Council of Ministers of the EU. The detailed analyses of expert-based national policy positions and voting data all brought evidence that a new cleavage has possibly appeared in the Council placing a group of the new member states (often together with a varying group of other 'old' member states) versus the rest. But this new dimension of contestation, even if it proves stable and enlargement-, rather than spending- or core/periphery-related, characterizes only a small proportion of all policy contestation in the Council. It is discernible in few policy areas of legislative decision-making, like environment, but not in the majority of cases. Moreover, even when close together and opposed to the other member states, the CEE countries have found themselves more often on the losing side of the negotiations. There is no evidence that they have managed to block any major policy initiatives.

The most visible effects of enlargement have been procedural (affecting the decision-making modes) and organizational, most importantly with respect to the Commission. It has been suggested that the accession of the new member states has led to bureaucratization and formalization in the Council (Best et al. 2009; Hagemann and De Clerck-Sachsse 2007), increased pre-cooking of decisions (Best et al. 2009; Hagemann and De Clerck-Sachsse 2007) and more work (Hagemann and De Clerck-Sachsse [2007]; see also Juncos and Pomorska [2006] for the case of CFSP). The procedural and organizational effects have been counteracted quite rapidly and successfully through organizational reforms and, some problems like the high number of Commissioners' portfolios notwithstanding, the EU has absorbed the newcomers without much pain. ${ }^{19}$ The Commission has successfully incorporated the thousands of new recruits from CEE since 2005 (see Ban [2013]; Dinan [2006]; and Bressanelli [2014] for the case of the European Parliament). As a result, the decision-making capacity has not been compromised by the organizational challenges in the post2004 era. 
Looking beyond aggregate-level patterns and system-level indicators, there is not much qualitative case-based evidence that many of the challenges, responses and conflicts that have pre-occupied the EU over the last 10 years can be traced back to the accession of CEE states. The institutional transformations that dominated the initial period after 2004 can only partly and indirectly be linked to the Eastern enlargement; the economic and financial troubles that dominated the years after 2007, even less so. If anything, it is quite surprising how little imprint the new member states have left on the history of European integration since 2004 and how few of the challenges facing the EU at the moment have to do with the absorption of the postcommunist member states.

The refugee crisis of 2015 and the policy response it has generated seemingly contradict this view. Many East European member states, including Hungary, Poland and Slovakia, are (as of mid-2016) strenuously opposed to the plans of the European Commission, which have the support of Germany and several other West European member states. However, not all 'new' states share the same position (for example, Bulgaria is much more open to the proposed idea of burden-sharing), and the opposition does not come only from the East (for example, it is also strong in Austria). Still, asylum policy remains a salient and rather visible example of a policy confrontation where fundamental differences in values between many 'old' and many 'new' member states exist.

The actual effects of enlargement on the decision-making capacity of the EU might be minor, but it is the perceived effects that might prove to be more consequential in the long run. Decision-making capacity is only one aspect of the internal dimension of the integration capacity of the EU (Börzel et al. 2017), but its perceived inadequacy can still undermine the entire construct.

\section{Notes}

1. The story was widely reported in the European press. For a sample, see the report by Matthew Holehouse 'EU quota plan forced through against eastern European states' wishes', published in The Telegraph on 23 September 2015, available online at: http://www.telegraph.co.uk/news/worldnews/europe/ 11883024/Europe-ministers-agree-relocation-of-120000-refugees-by-large-majority. html (last accessed 2 February 2016).

2. For details on this story, see Georgi Gotev's article 'EU leaders to clash over Nord Stream 2 at summit' published on 4 December 2015 by EurActiv, available online at: http://www.euractiv.com/sections/energy/eu-leaders-clash-over-nordstream-2-summit-320114 (last accessed 2 February 2016).

3. Decision-making capacity is a crucial component of policy-making capacity, which in its turn is a major aspect of the internal dimension of the integration capacity of the EU (Börzel et al. 2017).

4. According to the 2009 Flash Eurobarometer survey, 65 per cent of European citizens agreed with the statement that the integration of Central and Eastern 
European countries into the EU 'has made the European Union more difficult to manage'. On average, the percentage is even higher in the 'old' EU-15 - 69 per cent, and reaches 78 per cent for French and Austrian citizens (European Commission 2009: 30-2). This is the perceived negative consequence of the Eastern enlargement that most people would agree (European Commission 2009: 30; see also Toshkov et al. 2014).

5. For applications of the spatial model and the closely related veto players theory (Tsebelis 2002) to the analysis of EU decision making, see Steunenberg (1994), Tsebelis and Garrett (2000) and Thomson et al. (2012).

6. Two caveats about the use of legislative output as an indicator of capacity must be made. First, the number of legislative acts adopted does not take into account the importance of individual legal acts. Second, the theoretically relevant concept is not legislative output as such, but the ratio between the legislative output and the so-called 'systemic agenda' (the pressing issues facing society and the economy which demand the attention of law- and policy-makers). Unfortunately, neither the importance of individual legal acts nor the systemic agenda can be operationalized and measured for the case of the EU.

7. Data are derived from the Eur-lex legislative database. Where possible, the numbers exclude codifications and recasts.

8. In light of the 'Better regulation' programme (European Commission 2007) that was implemented in the years after 2006, it seems unlikely that the EU produces a comparable number of legal acts that have lower individual importance after enlargement.

9. This and the following figures are based on data extracted from PRELEX and made available by Frank Häge in the EUPOL dataset (http://frankhaege.eu). Recasts and codifications are excluded.

10. The data include positions on 158 issues part of 52 proposals. For each issue, the country positions, the positions of the Commission and the EP, and the reference point (most often the status quo policy) are measured on a common scale (ranging between 0 and 100). The measures are obtained from an expert survey.

11. Hosli et al. (2011) find evidence that there are different determinants of dissent for the old and the new member states based on data on voting in the Council. The determinants of dissent in the Council are explored in more detail in Hagemann and Høyland (2008) and Bailer et al. (2015).

12. See Arregui and Thomson (2014) and Høyland and Hansen (2014) for analyses of how the expert-based policy positions and the voting data are related. In short, preference distance from the outcome is probabilistically related to expressing dissent.

13. Negative votes and abstentions are combined together in the analysis, although clearly these two expressions of dissent have quite different legal consequences for the adoption or non-adoption of an act. Nevertheless, by combining them, as usual in the literature, we get more information from which to infer the underlying conflict space. Relying on negative votes only provides too little and too sparse information. Conceptually, negative votes and abstentions can be considered manifestations of a common concept - dissent.

14. The data are collected from the Monthly Summaries of Council Acts, available online at: http://www.consilium.europa.eu/documents/legislative-transparency/ monthly-summaries-of-council-acts. This source lists negative votes, abstentions and declarations made for all legislative acts, and sometimes for non-legislative acts as well. In general, the source can be considered reliable and complete. 
Note, however, that votes on Council Common Positions are treated inconsistently: sometimes voting outcomes on Common Positions would be available, but at other times not. The analyses below include votes on final legislative acts, and on Common Positions and non-legislative acts, when available.

15. The network is built with the Large Graph Layout $(I g l)$ as implemented in the igraph package for the $R$ statistical program. Layouts based on different algorithms, like Kamada-Kawai or Fruchterman-Reingold produce graphs which lack clustering to an even greater extent.

16. The distance measure used is the so-called 'Jaccard scores' which is appropriate for the binary data at hand. The Ward method for hierarchical clustering is used.

17. The model is a quadratic normal two-parameter item-response model fit via a Markov chain Monte Carlo algorithm. The overall approach is similar to the popular NOMINATE multi-dimensional scaling method (Poole and Rosenthal [1997]; for a discussion in the context of EU decision-making, see Hagemann [2007]).

18. Note that the UK values have been truncated for the figure to make the rest of the plot visible. In fact, the UK is much further away than plotted from the other member states on both dimensions.

19. It is worth noting that one of the greatest organizational challenges of EU decision-making - the rotating Presidencies of the European Council - have been handled quite successfully by the new member states, like Slovenia in 2008, Poland in 2011 and Lithuania in 2013, and satisfactory by the Czech Republic (2009) and Hungary (2011).

\section{Acknowledgements}

The author would like to thank Martin Kröger, Bernard Steunenberg, Antoaneta Dimitrova, Sara Hagemann, Asya Zheliazkova, Moritz Knoll, Karen Anderson, Karolina Pomorska and the participants at the MAXCAP Kick-off Conference (Berlin, 1 June 2013), MAXCAP Policy Brief (Sofia, February 2016) and the NIAS seminar 'Explaining European Union Decision-Making: Insights from the Natural and the Social Sciences' (Wassenaar, 16 December 2014) for useful comments and suggestions on earlier drafts. I would also like to extend my gratitude to Sara Hagemann, Frank Häge and Stefanie Bailer for responses to data inquiries and requests. A previous, longer version of this work is available as a MAXCAP working paper at http://www.maxcap-project.eu/ system/files/maxcap_wp_05_0.pdf

\section{Disclosure statement}

No potential conflict of interest was reported by the author.

\section{Funding}

Research for this paper has been supported by the FP7 programme of the EU (project 'Maximizing the integration capacity of the European Union: Lessons and prospects for enlargement and beyond' [MAXCAP]) under grant agreement number 320115.

\section{Notes on contributor}

Dimiter Toshkov is associate professor of public administration at Leiden University, The Netherlands. 


\section{References}

Arregui, J. and Thomson, R. (2014) 'Domestic adjustment costs, interdependence and dissent in the council of the European Union', European Journal of Political Research 53(4): 692-708.

Avery, G., Faber, A. and Schmidt, A. (2009) Enlarging the European Union: Effects on the New Member States and the EU, Brussels: Trans European Policy Studies Association.

Bailer, S., Hertz, R. and Leuffen, D. (2009) 'Oligarchization, formalization, adaptation? Linking sociological theory and EU enlargement research', Journal of European Public Policy 16(1): 162-74.

Bailer, S., Mattila, M. and Schneider, G. (2015) 'Money makes the EU go round: the objective foundations of conflict in the council of ministers', JCMS: Journal of Common Market Studies 53(3): 437-56.

Ban, C. (2013) Management and Culture in an Enlarged European Commission, Basingstoke: Palgrave Macmillan.

Best, E. and Settembri, P. (2008) 'Surviving enlargement: How has the Council managed?', in E. Best, T. Christiansen and P. Settembri (eds), The Institutions of the Enlarged European Union. Continuity and Change, Cheltenham: Edward Elgar, pp. 34-53.

Best, E., Christensen, T., Settembri, P. and Neuhold, C. (2009) 'Effects of enlargement on the EU's institutions \& decision-making - the EU institutions after enlargement: not quite business as usual', in G. Avery, A. Faber and A. Schmidt (eds), Enlarging the European Union: Effects on the New Member States and the EU, Brussels: Trans European Policy Studies Association, pp. 112-24.

Börzel, T.A., Dimitrova, A. and Schimmelfennig, F. (2017) 'EU enlargement and integration capacity: concepts, findings and implications', Journal of European Public Policy, doi:10.1080/13501763.2016.1264083

Bressanelli, E. (2014) 'Necessary deepening? How political groups in the European Parliament Ad apt to enlargement', Journal of European Public Policy 21(5): 776-92.

Clinton, J., Jackman, S. and Rivers, D. (2004) 'The statistical analysis of roll call data', American Political Science Review 98: 355-70.

Dinan, D. (2006) 'Governance and institutional developments: in the shadow of the constitutional treaty', JCMS: Journal of Common Market Studies 44: 63-80.

Enelow, J. and Hinich, M. (1984) The Spatial Theory of Voting: An Introduction, Cambridge: Cambridge University Press.

European Commission (2007) Communication from the Commission to the Council, the European Parliament, the European Economic and Social Committee and the Committee of the Regions. Action Programme for Reducing Administrative Burdens in the European Union. Brussels, 24.1.2007. COM(2007) 23 final.

European Commission (2009) 'Views on European Union Enlargement', Flash Eurobarometer 257, Brussels: European Commission.

Golub, J. (2007) 'Survival analysis and European Union decision-making', European Union Politics 8(2): 155-79.

Häge, F. and Toshkov, D. (2011) Anticipating resistance: the effect of member state preferences on the European Commission's agenda-setting activity. University of Limerick PPA Working Papers.

Hagemann, S. (2007) 'Applying ideal point estimation methods to the council of ministers', European Union Politics 8(2): 279-96.

Hagemann, S. and De Clerck-Sachsse, J. (2007) 'Decision-making in the enlarged council of ministers: evaluating the facts', CEPS Policy Brief (127): 1-8. 
Hagemann, S. and De Clerck-Sachsse, J. (2007) 'Decision-making in the enlarged council of ministers: evaluating the Facts', CEPS Policy Brief No. 119, Brussels: Centre for European Policy Studies.

Hagemann, S. and Høyland, B. (2008) 'Parties in the council?', Journal of European Public Policy 15(8): 1205-21.

Hagemann, S., Bailer, S. and Herzog, A. (2014) 'Signals to their parliaments. Governments' strategic use of votes and policy statements in the EU Council', Paper presented at the FRIAS workshop "Foreign Policy Changes and International Norms. Examining Internal and External Determinants", University of Freiburg, 23-24, October.

Hertz, R. and Leuffen, D. (2011) 'Too big to run? Analysing the impact of enlargement on the speed of EU decision-making', European Union Politics 12(2): 193-215.

Hosli, M.O., Mattila, M. and Uriot, M. (2011) 'Voting in the council of the European Union after the 2004 enlargement: a comparison of old and new member states', JCMS: Journal of Common Market Studies 49(6): 1249-70.

Høyland, B. and Hansen, V.W. (2014) 'Issue-specific policy-positions and voting in the council', European Union Politics 15(1): 59-81.

Juncos, A. and Pomorska, K. (2006) Playing the Brussels game: strategic socialisation in the CFSP Council Working Groups. European Integration online Papers (EloP) 10.

Kelemen, R.D., Menon, A. and Slapin, J. (2014) 'Wider and deeper? Enlargement and integration in the European Union', Journal of European Public Policy 21(5): 647-63

Klüver, H. and Sagarzazu, I. (2013) 'Ideological congruency and decision-making speed: the effect of partisanship across European Union institutions', European Union Politics 14(3): 388-407.

König, T. (2007) 'Divergence or convergence? From ever-growing to ever-slowing European legislative decision making', European Journal of Political Research 46(3): 417-44.

König, T. and Bräuninger, T. (2002) 'From an ever-growing towards an ever-slower union?', in M. Hosli, A. van Deemen and M. Widgrén (eds), Institutional Challenges in the $E U$, London: Routledge, pp. 243-59.

König, T. and Bräuninger, T. (2004) 'Accession and reform of the European Union: A game-theoretical analysis of eastern enlargement and the constitutional reform', European Union Politics 5(4): 419-39.

Lenz, H. and Hagemann, S. (2014) 'Transparency vs. efficiency? A study of negotiations in the council of the European Union', Paper presented at the 2014 Annual Meeting of the American Political Science Association, available at http://ssrn.com/abstract= 2453146

Leuffen, D. (2006) 'Breaking the Camel's back? Eastern enlargement and EU governance', Paper presented at the ECPR's Third Pan-European Conference on European Politics, Istanbul, 21-23, September.

Leuffen, D. and Hertz, R. (2010) 'If things can only get worse: anticipation of enlargement in European Union legislative politics', European Journal of Political Research 49(1): 53-74.

Mattila, M. (2009) 'Roll call analysis of voting in the European Union Council of ministers after the 2004 enlargement', European Journal of Political Research 48(6): 840-57.

Plechanovova, B. (2011) 'The EU council enlarged: north-south-east or core-periphery?', European Union Politics 12(1): 87-106.

Plechanovová, B. (2013) 'National actors in the post-Lisbon EU: should we expect a change of national strategies?', West European Politics 36(6): 1199-220. 
Poole, K. and Rosenthal, H. (1997) Congress: A Political-Economic History of Roll Call Voting, New York: Oxford University Press.

Rasmussen, A. and Toshkov, D. (2013) 'The effect of stakeholder involvement on legislative duration: consultation of external actors and legislative duration in the European Union', European Union Politics 14(3): 366-87.

Settembri, P. (2007) 'The surgery succeeded. Has the patient died? The impact of enlargement on the European Union', Jean Monnet Working Paper 04/07, New York, NY. 2007: NYU School of Law, accessible at http://www.jeanmonnetprogram.org/ papers/07/070401.html

Steunenberg, B. (1994) 'Decision making under different institutional arrangements: legislation by the European Community', Journal of Institutional and Theoretical Economics (JITE) / Zeitschrift fur die GesamteStaatswissenschaft 150(4): 642-69.

Steunenberg, B. (2002) An even wider Union: 'The effects of enlargement on EU decision-making', in B. Steunenberg (ed.), Widening the European Union: The Politics of Institutional Change and Reform, London: Routledge, pp. 97-118.

Thomson, R. (2009) 'Actor alignments in the European Union before and after enlargement', European Journal of Political Research 48(6): 756-81.

Thomson, R., et al. (2012) 'A new dataset on decision-making in the European Union before and after the 2004 and 2007 enlargements (deuii)', Journal of European Public Policy 19(4): 604-22.

Toshkov, D. and Rasmussen, A. (2012) Time to decide: the effect of early agreements on legislative duration in the EU. European Integration Online Papers, Vol. 16, Art. 11.

Toshkov, D., Kortenska, E., Dimitrova, A. and Fagan, A. (2014) 'The 'Old' and the 'New' Europeans: analyses of public opinion on EU enlargement in review', MAXCAP Working Paper No. 2, available at http://www.maxcap-project.eu/publications/ working-papers.

Tsebelis, G. (2002) Veto Players: How Political Institutions Work, Princeton: Princeton University Press.

Tsebelis, G. and Garrett, G. (2000) 'Legislative politics in the European Union', European Union Politics 1: 9-36.

Veen, T. (2011) 'The dimensionality and nature of conflict in European Union politics: on the characteristics of intergovernmental decision-making', European Union Politics 12(1): 65-86.

Zimmer, C., Schneider, G. and Dobbins, M. (2005) 'The contested council: conflict dimensions of an intergovernmental EU institution', Political Studies 53(2): 403-22. 